\title{
ANALISIS KOMPARASI INVESTASI DINAR DAN INVESTASI REKSADANA PASAR UANG SYARIAH
}

\author{
Nur Ayu Eva Feriyani*
}

\begin{abstract}
Comparative Analysis between Dinar Investment and Sharia Money Market Mutual Funds. The aim of the study is to analyse return and risk in Dinar Investment and Syariah Money Market Mutual Funds which result from movement Price Dinar and NAB Reksadana Pasar Uang Syariah at period of January 2008 untill December 2012. The study used t test that resulted of expected return dinar equal to 1,56\% while Sharia Money Market Mutual Fund equal to 2,74\%. And risk Dinar equal to 5,65\% while Sharia Money Market Mutual Fund equal to 55,6\%. Based on the analyses of return Sharia Money Market Mutual Fund better than Dinar. however Sharia Money Market Mutual Fund has significant higher than Dinar.
\end{abstract}

Keywords: investment, dinar, sharia money market mutual fund

\begin{abstract}
Abstrak: Analisis Komparasi Investasi Dinar dan Investasi Reksadana Pasar Uang Syariah. Penelitian ini dimaksudkan untuk menganalisis return dan risiko dalam Investasi Dinar dan Reksadana Pasar Uang Syariah yang dihasilkan dari pergerakan harga Dinar dan NAB Reksadana Pasar Uang Syariah pada periode Januari 2008 sampai Desember 2012. Penelitian ini menggunakan uji t dengan hasil yang diharapkan bahwa dinar setara dengan 1,56\% sedangkan Pasar Uang Reksadana Syariah sebesar 2,74\%. Dan risiko Dinar sebesar 5,65\% sedangkan Pasar Uang Reksadana Syariah sebesar 55,6\%. Berdasarkan analisis pengembalian Syariah Pasar Uang Reksadana yang lebih baik ketimbang Dinar. Dengan demikian, persentase Pasar Uang Reksadana Syariah jauh lebih tinggi ketimbang Dinar.
\end{abstract}

Kata Kunci: investasi, dinar, reksadana pasar uang syariah

Naskah diterima: 21 Maret 2013, direvisi: 12 Mei 2013, disetujui: 16 Mei 2013.

${ }^{*}$ Himpunan Ilmuwan dan Sarjana Syariah Indonesia (HISSI); Jl. Ir. H. Juanda 95, Ciputat, Jakarta Selatan; E-mail: eva_veriyani@gmail.com. 


\section{Pendahuluan}

Banyak di antara kita sadar akan pentingnya investasi, tetapi tidak banyak yang mengetahui tujuan investasi. Bahkan, yang lebih parah, masih ada yang belum bisa membedakan arti menabung dengan berinvestasi. Hal mendasar yang membedakan antara menabung dengan berinvestasi adalah adanya ketidakjelasan dalam beberapa hal. Pertama, tujuan atau kebutuhan secara spesifik, misalnya untuk pendidikan anak, memiliki rumah, atau persiapan pensiun. Kedua, seberapa besar dana yang akan dibutuhkan untuk tujuan dimaksud. Ketiga, kapan kebutuhan itu diperlukan dan berapa lama (jangka waktu) untuk mencapai waktu tersebut. Keempat, pilihan/alternatif investasi yang tersedia untuk mencapai tujuan tersebut. Kelima, strategi mencapai tujuan tersebut. ${ }^{1}$

Bentuk pilihan investasi sangat banyak, ada yang menanamkan modal di perusahaan atau perdagangan. Penawaran untuk melakukan investasi pun sangat marak. Seperti reksadana, saham, obligasi, deposito, dan sebagainya. Investasi adalah komitmen sejumlah dana untuk tujuan memperoleh keuntungan di masa yang akan datang. Inilah sebenarnya yang menjadi tujuan ketika seseorang memutuskan untuk berinvestasi. Namun demikian, harapan memperoleh keuntungan tersebut tidak lepas dari kemungkinan terjadinya risiko. Investasi sebagai sebuah perencanaan keuangan seseorang di masa yang akan datang harus memperhatikan faktor tersebut. Bagi para perencana keuangan, inflasi adalah faktor ketidakpastian terbesar yang paling sulit dihindari. Inflasi ini terjadi karena penurunan daya beli uang, yang disebabkan nilai nominal mata uang kertas tidak sama dengan nilai intirinsiknya. ${ }^{2}$

Indonesia duduk sebagai salah satu produsen emas terbesar di dunia. Pada tahun 2012 Kementrian Energi dan Sumber Daya Mineral merilis produksi emas Indonesia mencapai 111 ton. Namun dari sisi sebagai konsumen, negara ini masih kalah dari India dan Cina. Emas dikenal luas sebagai salah satu komoditi lindung nilai. Nilai mata uang boleh naik turun, tapi emas tidak terpengaruh oleh kondisi itu karena karakternya yang zero inflation.Kenaikan harga emas pun akan selalu diatas inflasi terbukti dari tahun ke tahun kenaikannya pun cukup signifikan, yaitu antara $20-40 \%$ pertahun. $^{3}$

Investasi emas juga likuid, dari bentuk perhiasan hingga batangan bisa dijual di sembarang tempat, tapi ke ribuan dealer/toko emas di seluruh Indonesia, PT. Antam Jakarta dan Surabaya, Wakala, Gerai Dinar, atau ke orang lain.

${ }^{1}$ Eko P. Pratomo, Berwisata ke Dunia Reksadana, (Jakarta: PT. Gramedia Pustaka Utama, 2007), h. 5.

${ }^{2}$ Muhaimin Iqbal, Dinar Solution (Dinar Sebagai Solusi).

${ }^{3}$ Majalah Sharing Edisi 57 Tahun V September 2011, h. 28. 
Menurut Palaloi, investasi emas bukan hanya demi imbal hasil yang tinggi, juga misi sosial, yaitu memeratakan pendapatan. Investasi emas juga harus diniatkan untuk ibadah, mulai dengan nominal yang kecil sekalipun. Jika Investasi emas tersebut cukup untuk melunasi niat di atas, maka pencairan emas dimanfaatkan untuk mendapatkan faktor produksi atau untuk beribadah. Return dari faktor produksi tersebut disisihkan untuk investasi emas lagi. Selanjutnya kembali lagi ke niat untuk investasi emas. Begitulah siklus investasi emas tanpa mengeluarkan zakat, infak, sedekah, dan instrumen tabarru' lainnya. ${ }^{4}$

Mata uang dinar kebal akan krisis. Nilainya sepanjang waktu terus stabil. Bahkan, selalu meningkat apabila dikonversikan dengan mata uang fiat, seperti rupiah, bahkan dollar AS sekalipun. Menurut Iqbal, nilai Dinar ini baku tidak terdevaluasi, sehingga, nilai satu Dinar zaman Khalifah 'Umar ibn al-Khaththâb sama dengan nilai dinar zaman sekarang, yaitu setara dengan emas 4,25 gram. ${ }^{5}$

Tabel $1^{6}$

Perkembangan Harga Dinar dari Tahun 2007-2011

\begin{tabular}{cc}
\hline Tahun & Harga Dinar \\
\hline 2007 & 975,000 \\
\hline 2008 & $1,371,443$ \\
\hline 2009 & $1,453,000$ \\
\hline 2010 & $1,758,430$ \\
\hline Nov2011 & $2,231,888$ \\
\hline
\end{tabular}

Sumber: Brosur Wakala Nusantara

Menurut pendapat sebagian Masyarakat, reksadana adalah investasi yang mudah didapat, selain risiko yang rendah dan return yang stabil. Tapi, di sisi lain kenaikan harga dinar sangat menggiurkan masyarakat untuk berinvestasi pada Dinar namun masyarakat masih ragu untuk berinvestasi pada dinar karena mereka belum mengetahui risiko berinvestasi pada Dinar.

\section{Beberapa Terminologi}

Pertama, investasi. Investasi adalah komitmen atas sejumlah dana atau sumber daya lainnya yang dilakukan pada saat ini, memperoleh sejumlah

\footnotetext{
${ }^{4}$ Majalah Sharing Edisi 36 Tahun IV Desember 2009, h. 10.

${ }^{5}$ Majalah Sharing Edisi 27 Tahun III Maret 2009, h.12.

${ }^{6}$ Brosur Wakala Nusantara.
} 
keuntungan di masa datang. ${ }^{7}$ Investasi adalah penundaan konsumsi sekarang untuk digunakan di dalam produksi yang efisien selama periode waktu tertentu. ${ }^{8}$

Investasi yang islami adalah Pengorbanan sumber daya pada masa sekarang untuk mendapatkan hasil yang pasti, dengan harapan memperoleh hasil yang lebih besar di masa yang akan datang, baik langsung maupun tidak langsung seraya tetap berpijak pada prinsip-prinsip syariah secara menyeluruh (kâffah). ${ }^{9}$

Hal Mendasar yang membedakan menabung dengan berinvestasi adalah adanya ketidakjelasan dalam hal: ${ }^{10}$ (1) Tujuan atau kebutuhan secara spesifik, misalnya untuk pendidikan anak, memiliki rumah, atau persiapan pension; (2) seberapa besar dana yang akan dibutuhkan untuk tujuan dimaksud; (3) Kapan kebutuhan itu diperlukan dan berapa lama (jangka waktu) untuk mencapai waktu tersebut; (4) Pilihan/alternatif investasi yang tersedia untuk mencapai tujuan tersebut; (5) Strategi mencapai tujuan tersebut.

Kedua, Dinar dan Dirham. Dinar adalah koin yang terbuat dari emas, yang merupakan logam yang bersifat lunak dan mudah ditempa. Sedangkan Dirham adalah koin yang terbuat dari perak yang memiliki karakteristik seperti emas, yaitu mudah dilebur dan ditempa kembali. Kata Dinar sendiri sebetulnya bukan berakar dari bahasa Arab, melainkan bahasa Yunani (Bizantium) atau bahkan mungkin berasal dari bahasa Persia, dinarius. Sementara kata Dirham berasal dari kata Drachma yang berarti mata uang yang terbuat dari perak. ${ }^{11}$

Ketiga, reksadana. Menurut undang-undang Pasar Modal no.8 tahun 1995, pasal 1 ayat 27, Reksadana adalah suatu wadah yang dipergunakan untuk menghimpun dana dari masyarakat pemodal untuk selanjutnya diinvestasikan dalam portofolio efek oleh manajer investasi yang telah mendapat izin dari Bapepam. ${ }^{12}$

Menurut Fatwa DSN No. 20 / DSN-MUI/IV/2001, Reksadana Syariah adalah Reksadana yang beroperasi menurut ketentuan dan prinsip syariah Islam, baik dalam bentuk akad antara Pemodal milik harta (shâhib al-mâl) dengan Manager

${ }^{7}$ Eduardus Tandeilin, Portofolio dan Investasi Teori dan Aplikasi, (Yogyakarta: Kanisius, 2010), h. 7 .

${ }^{8}$ Agus Edi Sumanto, "Materi Kuliah Manajemen Investasi dan Risiko", Pada Sabtu 27 Maret 2010

${ }^{9}$ Muhammad Nafik HR, Bursa Efek dan Investasi Syariah, (Jakarta: 2009), h. 70.

${ }^{10}$ Eko P.P ratomo, Berwisata ke Dunia Reksadana, (Jakarta: PT. Gramedia Pustaka Utama, 2007), h. 5.

${ }^{11}$ M. Luthfi Hamidi, Gold Dinar (Sistem Moneter Global yang stabil dan Berkeadilan), Jakarta: Senayan Abadi Publishing, 2007), h. 81.

${ }^{12}$ Eko P. Pratomo, Berwisata ke Dunia Reksadana, (Jakarta: PT. Gramedia Pustaka utama, 2007), h. 35. 
Investasi sebagai wakil shâhib al-mâl, maupun antara Manager Investasi sebagai wakil shâhib al-mâl dengan pengguna investasi. ${ }^{13}$

Reksadana syariah (Islamic Investment Funds) dalam hal ini memiliki pengertian yang sama dengan reksadana konvensional, hanya saja cara pengelolaan dan kebijakan investasinya harus berdasarkan pada syariat islam, baik dari segi akad, pelaksanaan investasi, maupun dari segi pembagian keuntungan. ${ }^{14}$

Ada empat jenis reksadana menurut jenis investasinya. Pertama, reksadana pendapatan tetap (fixed income fund). Yakni reksadana yang melakukan investasi sekurang-kurangnya $80 \%$ dari portfolio yang dikelolanya ke dalam efek yang bersifat hutang. Efek yang bersifat hutang umumnya memberikan penghasilan dalam bentuk bunga, seperti deposito, obligasi syariah, SWBI, dan Instrumen lainnya.

Keuntungannya lebih besar dari reksadana pasar uang selain itu, tingkat risikonya juga lebih besar. Biasanya keuntungan dibayar secara tunai (deviden) dan teratur misalnya tiga bulan, enam bulan, atau tahunan. Tujuannya adalah untuk menghasilkan keuntungan yang stabil.

Kedua, reksadana campuran (discretionary fund/mixed fund). Reksadana campuran dapat melakukan investasinya dalam bentuk efek hutang maupun ekuitas dengan porsi alokasi yang lebih fleksibel. Artinya, melihat sisi fleksibilitas baik dalam pemilihan jenis investasi (saham, obligasi, deposito atau efek lainnya) serta komposisi alokasinya, RDC dapat berorientasi pada orientasinya pada pasar uang, obligasi, saham, deposito.

Mengingat komposisinya yang variatif, sebelum menentukan pilihan pada suatu RDC tertentu, investor harus benar-benar mengetahui, bagaimana komposisi investasi yang terdapat pada RDC yang akan dipilih. Hal ini dapat dilakukan dengan mempelajari propektus reksadana.

Ketiga, reksadana pasar uang. Yakni reksadana yang investasinya 100\% pada efek pasar uang. Efek pasar uang adalah efek-efek hutang yang berjangka kurang dari satu tahun. Instrumentnya adalah Deposito, SBI, obligasi, serta efek hutang lainnya.Low Profit, Low Risk.

Tujuannya untuk kepentingan perlindungan modal dan untuk menyediakan likuiditas yang tinggi, sehingga jika dibutuhkan dapat dicairkan setiap hari kerja dengan risiko penurunan nilai investasinya hampir tidak ada. Untuk memberikan hasil yang lebih tinggi, RDPU dapat memanfaatkan tingkat suku bunga yang lebih tinggi di bank atau dengan menginvestasikan sebagian dananya di SBI

\footnotetext{
${ }^{13}$ Sofiyani Ghufron, Investasi halal di Reksadana Syariah, Jakarta, Renaisan, 2005, hal. 15

${ }^{14}$ Sofiyani Ghufron, Investasi halal di Reksadana Syariah, Jakarta, Renaisan, 2005hal 8
} 
yang pada suatu saatnya bisa memberikan hasil yang lebih tinggi dibandingkan deposito atau obligasi yang akan jatuh tempo kurang dari satu tahun.

Keempat, reksadana saham (RDS). Yakni reksadana yang melakukan investasi sekurang-kurangnya $80 \%$ dari portofolio yang dikelolanya ke dalam efek bersifat ekuitas (saham). Efek saham pada umumnya memberikan hasil yang lumayan tinggi, berupa capital gain melalui pertumbuhan harga-harga saham dan dividen.

Investasi pada saham merupakan investasi jangka panjang yang menjanjikan. Investasi ini merupakan salah satu alternatif yang paling tepat bagi investor yang tidak berani melakukan investasi di saham secara langsung, karena terbatasnya untuk menganalisa dan memilih saham, terbatasnya dana untuk melakukan diversifikasi, serta terbatasnya waktu untuk memonitor kondisi pasar.

\section{Pergerakan Harga Dinar dan NAB Reksadana Pasar Uang Syariah}

Pergerakan harga Dinar rata-rata atau moving average Dinar digunakan untuk menganalisis harga Dinar, dengan tujuan menghitung rata-rata bergerak yang menunjukkan arah pergerakan Dinar periode tertentu.

Pergerakan harga Dinar disajikan dalam bentuk grafik dengan periode empat tahun atau selama 48 bulan, dimulai pada bulan Januari 2008 sampai dengan bulan Desember 2011. Harga Dinar yang digunakan adalah harga dinar di hari terakhir pada bulan yang diteliti yang mengacu pada harga dinar per hari yang diperoleh dari Gerai Dinar. Sedangkan data NAB (Nilai Aktiva Bersih) Reksadana PUAS diperoleh dari situs resmi Bapepam. Seperti juga Dinar, NAB reksadana PUAS disajikan dalam bentuk grafik dengan periode 4 tahun atau 48 bulan, dimulai pada bulan Januari 2008 sampai dengan bulan Desember 2011. Data NAB yang digunakan adalah NAB Reksadana PUAS yang telah disajikan dalam bentuk bulan oleh bapepam. Dan dapat diunduh kapan saja.

Adapun data harga Dinar dan NAB Reksadana PUAS bulanan periode Januari 2008 sampai Desember 2011 dapat dilihat pada tabel 4.1:

Tabel 2: Harga Dinar dan NAB Reksadana PUAS

\begin{tabular}{cclrc}
\hline No & Tahun & Bulan & Dinar (Rupiah) & NAB \\
\hline 1 & 2008 & Januari & $1,192,200$ & $330,992,636,067.00$ \\
\hline 2 & & Februari & $1,225,500$ & $303,467,643,557.00$ \\
\hline 3 & & Maret & $1,193,600$ & $351,495,680,068.00$ \\
\hline 4 & April & $1,127,100$ & $372,199,334,550.00$ \\
\hline 5 & Mei & $1,203,700$ & $414,264,968,279.00$ \\
\hline 6 & Juni & $1,193,200$ & $391,704,328,824.60$ \\
\hline 7 & & Juli & $1,161,630$ & $360,418,019,758.70$ \\
\hline
\end{tabular}




\begin{tabular}{|c|c|c|c|c|}
\hline 8 & & Agustus & $1,134,734$ & $321,447,601,834.75$ \\
\hline 9 & & September & $1,235,865$ & $203,130,890,136.78$ \\
\hline 10 & & Oktober & $1,192,426$ & $15,529,250,086.63$ \\
\hline 11 & & November & $1,379,757$ & $10,628,232,375.79$ \\
\hline 12 & & Desember & $1,327,434$ & $10,057,178,361.56$ \\
\hline 13 & 2009 & Januari & $1,440,727$ & $10,031,960,551.52$ \\
\hline 14 & & Februari & $1,605,055$ & $7,360,143,991.71$ \\
\hline 15 & & Maret & $1,515,172$ & $9,077,974,883.42$ \\
\hline 16 & & April & $1,336,526$ & $6,506,394,780.33$ \\
\hline 17 & & Mei & $1,411,759$ & $6,492,162,481.49$ \\
\hline 18 & & Juni & $1,350,917$ & $9,162,516,655.06$ \\
\hline 19 & & Juli & $1,321,869$ & $10,323,130,472.04$ \\
\hline 20 & & Agustus & $1,351,617$ & $8,796,285,407.48$ \\
\hline 21 & & September & $1,349,123$ & $8,863,133,360.22$ \\
\hline 22 & & Oktober & $1,393,982$ & $8,861,405,211.03$ \\
\hline 23 & & November & $1,540,770$ & $26,259,789,229.97$ \\
\hline 24 & & Desember & $1,444,036$ & $26,222,680,690.98$ \\
\hline 25 & 2010 & Januari & $1,400,029$ & $37,182,735,982.54$ \\
\hline 26 & & Februari & $1,443,804$ & $37,197,265,693.82$ \\
\hline 27 & & Maret & $1,400,122$ & $30,406,007,939.57$ \\
\hline 28 & & April & $1,470,082$ & $30,426,904,382.57$ \\
\hline 29 & & Mei & $1,532,275$ & $41,140,136,179.67$ \\
\hline 30 & & Juni & $1,552,167$ & $65,007,617,576.96$ \\
\hline 31 & & Juli & $1,462,647$ & $52,658,797,571.43$ \\
\hline 32 & & Agustus & $1,539,438$ & $52,011,782,566.78$ \\
\hline 33 & & September & $1,633,865$ & $67,194,823,760.47$ \\
\hline 34 & & Oktober & $1,677,143$ & $53,003,693,073.03$ \\
\hline 35 & & November & $1,719,323$ & $52,332,718,722.65$ \\
\hline 36 & & Desember & $1,762,976$ & $59,159,396,685.27$ \\
\hline 37 & 2011 & Januari & $1,676,423$ & $46,384,529,084.80$ \\
\hline 38 & & Februari & $1,741,073$ & $41,545,918,251.23$ \\
\hline 39 & & Maret & $1,790,003$ & $65,787,025,890.33$ \\
\hline 40 & & April & $1,927,376$ & $60,323,000,499.24$ \\
\hline 41 & & Mei & $1,884,735$ & $24,812,402,069.79$ \\
\hline 42 & & Juni & $1,857,990$ & $25,564,528,748.86$ \\
\hline 43 & & Juli & $1,981,406$ & $26,073,414,992.87$ \\
\hline 44 & & Agustus & $2,241,545$ & $25,225,138,688.92$ \\
\hline 45 & & September & $2,326,572$ & $34,988,351,470.66$ \\
\hline 46 & & Oktober & $2,248,051$ & $26,538,015,396.51$ \\
\hline 47 & & November & $2,265,846$ & $25,654,189,834.33$ \\
\hline 48 & & Desember & $2,140,855$ & $25,023,589,498.51$ \\
\hline
\end{tabular}

Sumber: Gerai Dinar dan www.bapepam.go.id

Berdasarkan data menunjukkan harga perolehan Dinar yang tertinggi pada bulan ke-45 atau periode bulan September 2011. Sedangkan yang terendah 
terjadi pada bulan keempat atau periode April 2008. Dinar tidak akan pernah berkurang nilainya, karena emas memiliki nilai nominal sama dengan interinsiknya. Meskipun ada beberapa periode yang mengalami penurunan, tetapi nilai dinar akan kembali stabil. Penyebabnya adalah nilai mata uang kertas yang selalu menyusut terhadap daya beli masyarakat. Jadi, emas akan selalu terlihat stabil dan kalaupun ada kenaikan atau penurunan bukan terhadap nilai emas tersebut, tetapi nilai mata uang yang digunakan sebagai konversi nilai emas yang menyusut terhadap mata uang lainnya.

Berdasarkan data menunjukkan return tertinggi ada pada bulan ke 11 atau periode bulan November 2008 dan return terendah ada pada bulan ke 48 atau bulan Desenber 2011. Fluktuasi return Dinar yang cukup signifikan ini disebabkan oleh harga emas dunia dan nilai tukar Rupiah terhadap Dolar Amerika. Kedua Faktor tersebut sangat menentukan harga dinar karena Dinar memiliki acuan emas standar Internasional. Ketika harga emas dunia naik dan nilai tukar rendah, maka harga Dinar dalam kondisi yang baik. Tetapi akan berbanding terbalik ketika harga emas dunia baik dan nilai tukar rupiah tinggi, ini akan mengakibatkan harga dinar naik pula.

Dengan merujuk kepada data, hasil return dan expected return $\mathrm{E}(\mathrm{Ri})$ yang merupakan pembagian dari total return dibagi jumlah periode penelitian, didapatkan bahwa reksadana yang penulis teliti selama periode penelitian mempunyai return negatif. Return tertinggi ada pada bulan November 2009, sedangkan return terendah ada pada bulan Oktober 2008. Hal ini dikarenakan krisis ekonomi global yang terjadi pada bulan Oktober 2008 lalu. Reksadana ini terkena rush, nasabah pemilik account reksadana PUAS PNM menarik dana mereka secara besar-besaran, yang mengakibatkan tingkat imbal hasilnya atau NABnya jatuh.

\section{Pengembalian yang Diharapkan (Expected Return) atas Dinar dan Reksadana Pasar Uang Syariah}

Setelah mengumpulkan data harga Dinar dan NAB Reksadana PUAS secara bulanan, maka langkah selanjutnya adalah menghitung pengembalian yang diharapkan (expected return) atas Dinar dan Reksadana PUAS.

Sebelum menghitung pengembalian yang diharapkan (expected return) dinar dan reksadana PUAS, perlu diketahui masing-masing return dari data harga dinar dan NAB Reksadana PUAS dengan rumus yang telah dipaparkan pada bab sebelumnya, yaitu persamaan (2.1). Cara yang digunakan adalah nilai akhir asset $\left(P_{i}\right)$ dan kemudian selisih tersebut dibagi dengan nilai awal asset $\left(P_{i-1}\right)$, hasilnya adalah return dari masing-masing data. Selanjutnya, untuk mengetahui pengem- 
balian yang diharapkan (expected return) dapat digunakan cara mengetahui rata-rata return dari data tersebut.

Berikut adalah hasil perhitungan return dari masing-masing data (actual return) Dinar dan Reksadana PUAS.

Tabel 3: Return Dinar dan Reksadana PUAS

\begin{tabular}{|c|c|c|c|c|}
\hline No & Tahun & Bulan & Return Dinar & Return NAB \\
\hline 1 & 2008 & Januari & 0.0869 & 0.0701 \\
\hline 2 & & Februari & 0.0279 & -0.0832 \\
\hline 3 & & Maret & -0.0260 & 0.1583 \\
\hline 4 & & April & -0.0557 & 0.0589 \\
\hline 5 & & Mei & 0.0680 & 0.1130 \\
\hline 6 & & Juni & -0.0087 & -0.0545 \\
\hline 7 & & Juli & -0.0265 & -0.0799 \\
\hline 8 & & Agustus & -0.0232 & -0.1081 \\
\hline 9 & & September & 0.0891 & -0.3681 \\
\hline 10 & & Oktober & -0.0351 & -0.9236 \\
\hline 11 & & November & 0.1571 & -0.3156 \\
\hline 12 & & Desember & -0.0379 & -0.0537 \\
\hline 13 & 2009 & Januari & 0.0853 & -0.0025 \\
\hline 14 & & Februari & 0.1141 & -0.2663 \\
\hline 15 & & Maret & -0.0560 & 0.2334 \\
\hline 16 & & April & -0.1179 & -0.2833 \\
\hline 17 & & Mei & 0.0563 & -0.0022 \\
\hline 18 & & Juni & -0.0431 & 0.4113 \\
\hline 19 & & Juli & -0.0215 & 0.1267 \\
\hline 20 & & Agustus & 0.0225 & -0.1479 \\
\hline 21 & & September & -0.0018 & 0.0076 \\
\hline 22 & & Oktober & 0.0333 & -0.0002 \\
\hline 23 & & November & 0.1053 & 1.9634 \\
\hline 24 & & Desember & -0.0628 & -0.0014 \\
\hline 25 & 2010 & Januari & -0.0305 & 0.4180 \\
\hline 26 & & Februari & 0.0313 & 0.0004 \\
\hline 27 & & Maret & -0.0303 & -0.1826 \\
\hline 28 & & April & 0.0500 & 0.0007 \\
\hline 29 & & Mei & 0.0423 & 0.3521 \\
\hline 30 & & Juni & 0.0130 & 0.5802 \\
\hline 31 & & Juli & -0.0577 & -0.1900 \\
\hline 32 & & Agustus & 0.0525 & -0.0123 \\
\hline 33 & & September & 0.0613 & 0.2919 \\
\hline 34 & & Oktober & 0.0265 & -0.2112 \\
\hline 35 & & November & 0.0251 & -0.0127 \\
\hline 36 & & Desember & 0.0254 & 0.1304 \\
\hline
\end{tabular}




\begin{tabular}{|c|c|c|c|c|}
\hline 37 & 2011 & Januari & -0.0491 & -0.2159 \\
\hline 38 & & Februari & 0.0386 & -0.1043 \\
\hline 39 & & Maret & 0.0281 & 0.5835 \\
\hline 40 & & April & 0.0767 & -0.0831 \\
\hline 41 & & Mei & -0.0221 & -0.5887 \\
\hline 42 & & Juni & -0.0142 & 0.0303 \\
\hline 43 & & Juli & 0.0664 & 0.0199 \\
\hline 44 & & Agustus & 0.1313 & -0.0325 \\
\hline 45 & & September & 0.0379 & 0.3870 \\
\hline 46 & & Oktober & $\begin{array}{l}-0.0337 \\
\end{array}$ & -0.2415 \\
\hline 47 & & November & 0.0079 & -0.0333 \\
\hline 48 & & Desember & -0.0552 & -0.0246 \\
\hline
\end{tabular}

Expected Return Dinar dan Reksadana PUAS

\begin{tabular}{lcr}
\hline & Dinar & Reksadana PUAS \\
\hline Expected Return / E ( R ) & 0.0156 & 0.0274 \\
\hline
\end{tabular}

Dari tabel di atas dapat diketahui bahwa E(R) Dinar adalah 0.0156 atau sebesar 1.56\%. Sedangkan E(R) Reksadana Pasar Uang Syariah adalah 0.0274 atau 2.74\%. Pada tabel di atas diketahui keuntungan yang diharapkan (Expected Return) terbesar adalah E(R) Reksadana PUAS, tetapi ini bukan berarti menimbulkan kesimpulan bahwa Reksadana PUAS lebih prospektif dibandingkan Dinar, karena risiko dari masing-masing instrument belum dilihat. Risiko dari Dinar dan Reksadana PUAS perlu diketahui karena merupakan penyimpangan dari return yang diharapkan terhadap pengembalian aktualnya.

\section{Risiko Dinar dan Reksadana Pasar Uang Syariah}

Setelah mengetahui pengembalian yang diharapkan, langkah selanjutnya adalah mengetahui tingkat risiko atas asset yang dijadikan instrument investasi. Pada dasarnya investor selalu dihadapkan dengan ketidakpastian memperoleh tingkat keuntungan tersebut menyimpang dari apa yang diharapkan. Oleh karena itu perlu diketahui tingkat penyimpangan risiko (suatu aset) menggunakan rumus pada persamaan (2.3) dan (2.4). Cara yang digunakan adalah dengan menghitung varian $\sigma^{2}$ dan standar deviasi $\sigma$ investasi tersebut. Karena standar deviasi dan varian dapat menunjukkan seberapa besar kemungkinan terjadinya risiko pada instrument investasi tersebut.

Kedudukan risiko di sini dapat disamakan dengan standar deviasi. Tabel dibawah ini merupakan perhitungan varian dan standar deviasi pada Dinar dan Reksadana PUAS: 
Tabel 4: Varian dan Standar Deviasi Dinar: Reksadana PUAS

\begin{tabular}{clccl}
\hline No & Instrument & Varian & STDEV & E(R) \\
\hline 1. & Dinar & 0.0032 & $5.65 \%$ & $1.56 \%$ \\
\hline 2. & Reksadana PUAS & 0.3092 & $55.6 \%$ & $2.74 \%$ \\
\hline
\end{tabular}

Tabel di atas menunjukkan varian Dinar 0.0032 dan standar deviasinya sebesar 5.65\%. Sedangkan pada Reksadana Pasar Uang sebesar 0.3092 dan standar deviasinya sebesar 55.6\%. Risiko tertinggi terletak pada Reksadana PUAS, tetapi tingkat pengembalian tertinggi terletak pada Reksadana PUAS yaitu sebesar $2.73 \%$. Tingkat risiko pada Dinar sangat kecil yaitu $5.75 \%$, begitu juga tingkat pengembalian pada Dinar tidak menunjukkan angka yang lebih besar yaitu $1.56 \%$. Dengan diketahuinya masing-masing risiko dan tingkat pengembalian dari Dinar dan Reksadana PUAS, maka bisa dijadikan perbandingan untuk mengetahui instrument mana yang lebih baik. Dapat dilihat melalui grafik di bawah ini:

Data menunjukkan posisi Dinar dan Reksadana PUAS berdasarkan Expected Return dan Risikonya. Reksadana PUAS berada pada posisi 2.74\% (Expected Return) dan 55.6\% (Risiko), sedangkan Dinar berada pada posisi $1.56 \%$ (Expected Return) dan 5.75\% (Risiko). Pada grafik di atas dapat dilihat bahwa posisi Reksadana PUAS lebih baik dibandingkan Dinar. Namun untuk lebih yakin dengan hal tersebut, maka akan dilakukan pengujian selanjutnnya.

\section{Optimalisasi Investasi Dinar dan Reksadana Pasar uang Syariah}

Langkah selanjutnya dalam analisis ini adalah mengetahui apakah ada perbedaan antara investasi Dinar dan Reksadana PUAS dengan metode perbandingan variabel bebas (uji t). Dalam analisis pengujian ini menggunakan pengujian dua arah (two tailed test) untuk mengetahui signifikansi perbedaan dua variabel atau dengan kata lain pengujian ini dilakukan untuk menentukan arah, kemudian dilanjutkan dengan pengujian satu arah (one tailed test) untuk mengetahui variabel mana yang paling unggul di antara Dinar dan Reksadana Pasar Uang Syariah. Karena sampel lebih dari 30 (n > 30), maka kedua pengujian ini menggunakan rumus Zo dengan menentukan nilai nyata atau probabilita.

Pertama, pengujian dua arah (two tailed test). Pengujian dua arah adalah pengujian terhadap suatu hipotesis yang belum diketahui arahnya. Seperti dua variabel reksa pasar uang syariah dengan Dinar memiliki perbedaan, maka harus ditentukan hipotesis yang menganggap bahwa dua sampel tersebut memiliki rata-rata yang berbeda. Ini disajikan dalam bentuk hipotesa nol $\left(\mathrm{H}_{0}\right)$ dan hipotesa alternatif $\left(\mathrm{H}_{\mathrm{a}}\right)$ yaitu: 
Ho : $\mu 1=\mu 2$

Ha : $\mu 1 \neq \mu 2$, Jika dipaparkan dalam bentuk kalimat sebagai berikut :

$\mathrm{H}_{\mathrm{o}}$ : return dinar emas tidak memiliki perbedaan dengan return reksadana PUAS

$\mathrm{H}_{\mathrm{a}}$ : return Dinar emas memiliki perbedaan dengan return reksadana PUAS

Taraf signifikansi yang digunakan adalah sebesar $\alpha=0.05$, nilai kritis $z \alpha_{/ 2}=$ $\pm 1,96$. Ho tidak dapat ditolak bila $-1.96 \leq \mathrm{z} \leq 1.96$. dan Ho ditolak bila $\mathrm{z}>1.96$ atau $\mathrm{z}<-1.96$. Dalam kondisi seperti ini secara otomatis Ha tidak dapat ditolak. Untuk mengetahui nilai z, maka digunakan rumus:

$$
\begin{aligned}
& \mathrm{z}=\frac{X 1-X 2}{\sigma_{X_{1}-X_{2}}} \\
& \text { dengan } \sigma_{X_{1}-X_{2}}=\sqrt{\frac{S_{1}^{2}}{n_{1}}+\frac{S_{2}^{2}}{n_{2}}} \\
& \text { maka, } z=\frac{-0.0118}{0.087405}=-0.1350
\end{aligned}
$$

Dalam pengujian ini, terlihat bahwa $\mathrm{Z}_{\text {hitung }} \leq \mathrm{Z}_{\text {tabel }}$ atau $-\mathrm{z} \alpha_{/ 2} \geq \mathrm{z} \geq \mathrm{z} \alpha_{/ 2}(-1.96$ $\geq-0.1350 \geq 1.96$ ), ini berarti Ha ditolak dan Ho tidak dapat ditolak, ini menunjukkan sebuah kesimpulan bahwa tidak ada perbedaan return Dinar dan return Reksadana PUAS.

Kedua, pengujian satu arah (one tailed test). Pengujian satu arah adalah pengujian terhadap suatu hipotesis yang sudah diketahui arahnya. Seperti dua variabel Reksa Pasar Uang Syariah dengan Dinar, salah satu dari variabel tersebut memiliki return yang lebih unggul dibandingkan variabel lainnya. Maka, harus ditentukan hipotesa yang menganggap salah satu variabel tersebut memiliki return yang lebih unggul. Ini disajikan dalam bentuk hipotesa nol $\left(\mathrm{H}_{0}\right)$ dan hipotesa alternatif $\left(\mathrm{H}_{\mathrm{a}}\right)$ yaitu:

Ho : $\mu 1=\mu 2$

Ha : $\mu 1<\mu 2$, Jika dipaparkan dalam bentuk kalimat sebagai berikut:

Ho : return dinar emas sama dengan return reksadana PUAS

Ha : return reksadana PUAS lebih baik dibandingkan dengan return dinar emas

Taraf signifikansi yang digunakan adalah sebesar $\alpha=0.05$, nilai kritis z $\alpha=$ 1,645. Ho tidak dapat ditolak bila $\mathrm{z} \leq-1.645$ yang secara otomatis menolak $\mathrm{H}_{\mathrm{a}}$. 
dan $\mathrm{H}_{\mathrm{o}}$ ditolak bila $\mathrm{z}>-1.645$. Dalam kondisi seperti ini secara otomatis Ha tidak dapat ditolak. Untuk mengetahui nilai z, maka digunakan rumus:

$$
\begin{aligned}
& \mathrm{z}=\frac{X 1-X 2}{\sigma_{X_{1}-X_{2}}} \\
& \text { dengan } \sigma_{X_{1}-X_{2}}=\sqrt{\frac{S_{1}^{2}}{n_{1}}+\frac{S_{2}^{2}}{n_{2}}} \\
& \text { maka, } z=\frac{-0.0118}{0.087405}=-0.1350
\end{aligned}
$$

Perhitungan diatas menunjukkan bahwa $\mathrm{z} \leq \mathrm{z} \alpha(-0.1350 \leq 1.645)$, ini menujukkan Ha ditolak Ho tidak dapat ditolak. Karena Ha ditolak, hal ini menunjukkan bahwa return Dinar dan return Reksadana PUAS tidak memiliki perbedaan yang cukup signifikan, dan dapat disimpulkan bahwa return Dinar sama dengan return Reksadana PUAS.

Pengujian hipotesis memberikan sebuah kondisi yang mungkin saja terjadi, bahwa analisis uji t tidak ada perbedaan terhadap return Dinar dan return Reksadana PUAS. Hal ini dikarenakan adanya krisis keuangan global yang terjadi pada tahun 2008 yang menimpa keuangan dunia, dan berdampak kepada keuangan Indonesia. Dampak yang terjadi pada krisis keuangan global ini menyebabkan bursa efek di Indonesia sempat terhenti dan tidak menjalankan aktivitas selama dua hari, dikarenakan banyaknya efek sekuritas yang mengalami penurunan harga. Institusi-institusi di Amerika Serikat berusaha untuk melikuidasi aset-asetnya di negara lain, termasuk di Indonesia. Beberapa reksadana pasar uang melakukan kebijakan untuk membekukan aktivitas subscription dan redemption. Kepanikan investor yang mendorong mereka untuk menarik dananya dari reksadana pasar uang telah memaksa para MI untuk menjual asetaset dalam portfolio pada harga yang tidak bagus. Dan mengakibatkan banyak reksadana yang berbasis pasar uang mengalami kondisi rush yaitu pemilik account atau pemilik rekening reksadana yang menarik besar-besaran uangnya dan ini mengakibatkan imbal hasil reksa-dana mengalami penurunan yang sangat drastis.

Sedangkan pada Dinar risiko hanya pengaruh turunnya nilai mata uang Rupiah terhadap mata uang lainnya, khususnya Dollar Amerika yang digunakan sebagai ukuran bagi Dinar Indonesia, bukan karena risiko atas nilai emas itu sendiri. Nilai Emas akan selalu stabil karena dinar memiliki nilai sesuai dengan kondisi Dinar itu sendiri. Saat ini Dinar masih belum banyak diminati oleh masyarakat sebagai instrument investasi. Karena masyarakat masih minimnya pengetahuan masyarakat tentang dinar. Saat ini, instrument investasi yang sedang diminati masyarakat adalah emas batangan atau logam mulia. Masyarakat ber- 
bondong-bondong antri untuk memiliki logam mulia selain faktor pengetahuan masyarakat, agen yang menjual logam mulia lebih banyak dibandingkan Dinar.

Untuk kondisi perekonomian saat ini, bagi investor tidak ada perbedaan signifikan berinvestasi di Reksadana PUAS maupun Dinar, jika dilihat dari segi return, Reksadana PUAS lebih unggul dengan menunjukkan angka 2.74\% sedangkan return Dinar hanya menunjukkan angka $1.56 \%$. Jadi return Reksadana PUAS lebih unggul sebesar $1.18 \%$ dari return Dinar. Meskipun dari segi return Reksadana PUAS lebih unggul tapi, dari segi risiko reksadana PUAS sangat tinggi yaitu 55,6 \% sedangakan Dinar hanya memiliki risiko 5,75\%. Jika dibandingakan maka Reksadana PUAS dengan Dinar adalah 55,6 \% : 5,75 \% atau kurang lebih 1: 9,7 maka, jika dilihat dari segi risiko Dinar lebih unggul dibandingkan Reksadana PUAS. Namun berdasarkan penelitian sebelumnnya yang dilakukan oleh Anna Madania expected return dinar dan expected return SWBI memiliki perbedaan yang sangat signifikan yaitu E( R) Dinar 1,76\% sedangkan E (R) SWBI sebesar $0,46 \%$. Hal ini membuktikan bahwa Dinar lebih baik dibandingkan dengan SWBI dari segi expected return.

\section{Penutup}

Berdasarkan analisis komparasi Investasi Dinar dan Investasi Reksadana Syariah. Dengan menggunakan 48 sample dari bulan Januari 2008 hingga Desember 2011, dapat ditarik kesimpulan. Pertama, hasil pengujian berdasar-kan rumus tingkat pengembalian yang diharapkan (expected return) menunjuk-kan adanya perbedaan antara Dinar dan Reksadana PUAS. E(R) Dinar menun-jukkan angka sebesar 1.56\% sedangkan E(R) Reksadana PUAS sebesar 2.74\%. Risiko Dinar sebesar 5.65\% sedangkan risiko Reksadana PUAS sebesar 55.6\%. Dari data-data tersebut sudah bisa diambil kesimpulan bahwa Reksadana PUAS lebih unggul tingkat pengembaliannya meskipun risiko yang dimiliki Reksadana PUAS sangat tinggi dibandingkan Dinar. Akan tetapi, Investor harus lebih cermat lagi untuk memilih Instrument investasi bukan hanya sekedar tingkat pengem-baliannya saja melainkan juga dari tingkat risikonya. Agar lebih aman sebaiknya investor memilih instrument Dinar meskipun tingkat pengembaliannya kecil, namun risiko yang dimiliki dinar jauh lebih rendah dibandingkan Reksadana PUAS.

Kedua, hasil pengujian hipotesis menyatakan bahwa E(R) Dinar sama dengan $\mathrm{E}(\mathrm{R})$ Reksadana PUAS. Pada pengujian dua arah (two tailed test) diketahui bahwa $\mathrm{z} \leq \mathrm{z} \alpha(-0.1398 \leq 1.645)$, ini berarti $\mathrm{H}_{\mathrm{a}}$ ditolak dan $\mathrm{H}_{\mathrm{o}}$ tidak dapat ditolak, ini menunjukkan sebuah kesimpulan bahwa tidak ada perbedaan return Dinar dan return Reksadana PUAS. Untuk pengujian satu arah (one tailed test) ini dapat dilihat dari hasil $t$ hitung yang menunjukkan angka lebih kecil daripada $t$ 
tabel, yaitu bahwa $\mathrm{z} \leq \mathrm{z} \alpha(-0.1398 \leq 1.645)$, ini menujukkan $\mathrm{H}_{\mathrm{a}}$ ditolak dan $\mathrm{H}_{\mathrm{o}}$ tidak dapat ditolak dengan taraf signifikansi sebesar 5\%. Dapat disimpulkan bahwa expected return Dinar dan expected return Reksadana PUAS sama. []

\section{Pustaka Acuan}

Anggraeni, Tini, "Mata Kuliah Pasar Modal", Selasa 5 Oktober 2010 (tidak diterbitkan)

Boediono, Ekonomi Moneter", Yogyakarta: BPFE, 1999.

Brosur Wakala Nusantara.

Daniel, Moehar, Metode Penelitian Sosial Ekonomi, Jakarta: Bumi Aksara, 2002. Ghufron, Sofiyani, Investasi halal di Reksadana Syariah, Jakarta: Renaisan, 2005. Halim, Abdul, Analisis Investasi, Depok: Salemba Empat, 2003.

Hamidi, M. Luthfi, Gold Dinar (Sistem Moneter Global yang stabil dan Berkeadilan), Jakarta: Senayan Abadi Publishing, 2007.

Hasan, Ahmad, Mata Uang Islami Telaah Komprehensif Sistem Keuangan Islami, Ed. Terjemahan. Penerjemah: Saifurahman Barito dan Zulfikar Ali, Jakarta: PT. RajaGrafindo Persada, 2005.

Husnan, Suad, Dasar-dasar Teori Portofolio dan Analisis Sekuritas, Yogyakarta: UPP AMP YKPN, 2001.

Iqbal, Muhaimin, Dinar Solution (Dinar Sebagai Solusi), Jakarta: Gema Insani, 2008.

------------, Mengembalikan Kemakmuran Islam dengan Dinar dan Dirham, Depok: Spiritual Learning Centre, 2007.

Madania, Anna, Analisis Investasi Dinar, Jakarta: UIN Syarif Hidayatullah, 2009.

Majalah Sharing Edisi 27 Tahun III Maret 2009.

Majalah Sharing Edisi 36 Tahun IV Desember 2009.

Majalah Sharing Edisi 57 Tahun V September 2011.

Manan, Abdul, Aspek Hukum dalam Penyelenggaraan Investasi di Pasar Modal Syariah Indonesia, Jakarta: Kencana, 2009.

Manurung, Adler Haymans, Panduan Lengkap Reksadana Investasiku, Jakarta: PT. Kompas Media Nusantara, 2008.

Munir, Rinaldi, Bahan Kuliah Probabilitas dan Statistik, Sekolah Teknik Elektro dan Informatika ITB (tidak diterbitkan), 2006.

Nafik HR, Muhammad, Bursa Efek dan Investasi Syariah, Jakarta: Serambi, 2009.

Nopirin, Ekonomi Moneter Buku II, Yogyakarta: BPFE, 2000.

Pratomo, Eko P, Berwisata ke Dunia Reksadana, Jakarta: PT. Gramedia Pustaka utama, 2007.

Riduwan, Metode dan Teknik Menyusun Tesis, Bandung: Alfabeta, 2009. 
Rochaety, Ety, dkk, Metodologi Penelitian Bisnis dengan Aplikasi SPSS, Jakarta: Mitra Wacana Media, 2009.

Rodoni, Ahmad, Investasi Syariah", Jakarta: Lembaga Penelitian UIN Jakarta, 2009.

Saleh, Samsubar, Statistik Induktif, Yogyakarta: UPP AMP YKPN, 2001.

Saltian, Yoga, Analisis Perbandingan Risiko dan Tingkat Pengembalian Reksadana Syariah dan Reksadana Konvensional "Skripsi Fakultas Ekonomi Yogyakarta: UII, 2009.

Sarkaniputra, Murasa, Ilmu Ekonomi (Pengantar Ekonomi Moneter: suatu awalan). Bahan Pengajaran Ekonomi, Perbankan dan Asuransi Islam, Jakarta: UIN Syarif Hidayatullah, 2000.

Sarkaniputra, Murasa, Ruqyah Syar'iyyah: Teori, Model, dan Sistem Ekonomi" Jakarta: Al-Ishlah press \& STEI, 2009.

Setiawan, Aziz Budi, "Alternatif Investasi Islami, Jakarta: Paper Penelitian di The Indonesia Economic Intelligence, 2007.

Sumanto, Agus Edi, Materi Kuliah Manajemen Investasi dan Risiko, pada Sabtu 27 Maret (tidak diterbitkan)

Tandeilin, Eduardus, Portofolio dan Investasi Teori dan Aplikasi, Yogyakarta: Kanisius, 2010. 